\title{
Some Anti-oxidants, Phsysio-morphological, and Yield of Varying Rice Varieties Affected by Salinity Levels. Zayed, B. A. ${ }^{1}$; Rania A. Khedr ${ }^{2}$; A. A. Hadifa ${ }^{1}$ and Amira M. Okasha ${ }^{1}$ \\ ${ }^{1}$ Rice Research Department, Field Crops Research Institute,Sakha,KafrElsheikh,ARC, Egypt \\ ${ }^{2}$ Physiology Department, Field Crops Research Institute, Sakha, KafrElsheikh, ARC, Egypt.
}

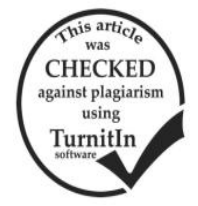

\begin{abstract}
Tow field experiments were conducted at El-Sirw Agricultural Research Station, Damietta Governorate, Egypt during 2015 and 2016 seasons. The main objectives of this study is to estimate the physiological and biochemical performance of some rice varieties under various salinity levels. The experiments were performed in randomized complete block design with four replicationsfor each salinity level apart and the results were statistically analyzed as split plot design after homogeneity test as combined. Soil survey of the experimental farm was annually done to find the following used salinity levels viz; $2,6 \mathrm{and}^{10 \mathrm{dSm}^{-}}$ ${ }^{1}$.Giza177, Giza178, Giza179 and Egyptian hybrid one (EHR1) ricevarieties were used. Anti -oxidants, physio- morphological and growth parameters were measured at heading stage as well as grain yield and yield attributing characteristics were measured at harvest. The obtained results indicated that: increasing salinity levels led up to decreased potassium percentage (K \%), increased sodium percentage $(\mathrm{Na} \%)$ and $\mathrm{Na}^{+} / \mathrm{K}^{+}$ratio in rice plant. Furthermore, increment of salinity levels reduced dry matter accumulation (g),relative water content $\mathrm{RWC}(\%)$, chlorophyll $\mathrm{a}, \mathrm{b}$ and total chlorophyll $\left(\mu \mathrm{g} \mathrm{ml}^{-1}\right)$ and, increased a/b ratio and antioxidant system peroxidase $(\mathrm{POD})\left(\mu \mathrm{mol} \mathrm{min}^{-1} \mathrm{~g}^{-1}\right.$ protein) Catalase $(\mathrm{CAT})\left(\mu \mathrm{mol} \mathrm{min}^{-1} \mathrm{~g}_{-}{ }^{1}\right.$ protein),proline $\left(\mathrm{mg} \mathrm{g}^{-1}\right.$ FW).Increasing salinity levels decreased the studied growth characteristics; flag leaf area, chlorophyll content (SPAD value), plant height, panicle weight, panicle length, number of filled grains, 1000-grain weight and grain yield/ha ${ }^{-1}$ but increased unfilled grains per panicle. EHR1gave the highest values of most studied characters followed by Giza179 while, Giza178 came in the third order. Giza177 gave the lowest values of the most studied traits. Egyptian hybrid one under the three salinity levels was distinction compared with other rice varieties in both seasons. Based on current biochemical and physiological traits and yield under different salinity levels, the tested rice varieties could be ranked as follows; EHR1>Giza179>Giza178 regarding their salinity tolerance. Giza 177 was found to be more salt sensitive variety.
\end{abstract}

\section{INTRODUCTION}

Salinity is one of the major abiotic stresses limiting crop productivity worldwide. Rice is a salt sensitive crop for soil salinity but it is the only crop that has been recommended as a desalinization crop due to its ability to grow under submerge conditions, also the standing water in rice fields can help to leach the salts from the topsoil to lower levels (Lafitte et al., 2004). Salinity affects major physiological and biochemical processes in plant. Rice plants which treated with $\mathrm{NaCl}(200 \mathrm{mMNaCl}, 14$ days) reduced of the Chlorophyll $\mathrm{b}$ content of leaves (41\%) than the Chl. a content (33\%) (Amirjani, 2011).Chutipaijit et al.( 2011) reported that rice exposed to $100 \mathrm{mMNaCl}$ showed 30\% and $45 \%$ in $\mathrm{Chl}$ a and $\mathrm{Chl} \mathrm{b}$, respectively. Surekha Rao et al.(2012) conducted that Chla, Chlb and total $\mathrm{Chl}$ showed a significant decrease under salinity stress.Chlorophyll $\mathrm{b}$ is more sensitive than chlorophyll a to salinity. Leaf relative water content (LRWC) is a measure of plant water status and reflects the metabolic activity of tissues and is used as a meaningful index for dehydration tolerance (Anjum et al., 2011). Salinity stress reduced RWC as compared with control plants. Amirjani(2010).

Salinity inducesreactine oxygen species (ROS) in plant cells and the excess production of ROS is toxic to plants and causes oxidative damage leading to cell death. Plants possess enzymatic and non-enzymatic antioxidant defense systems to protect cells against the damaging effects of ROS. (Hasegawa et al., 2000; Apel and Hirt, 2004 and Hossain et al., 2014). The major ROS-scavenging antioxidant enzymes are catalase (CAT) and guaiacol peroxidase (POX) and the main non-enzymatic antioxidant is proline. Catalase and peroxidase are the $\mathrm{H}_{2} \mathrm{O}_{2}$ detoxifying enzymes and mostly associated with peroxisomes where they remove $\mathrm{H}_{2} \mathrm{O}_{2}$ formed during photorespiration. Many authors have reported that salt stress strongly affects the components of antioxidant defense system in plants, (Noctor and Foyer, 1998; Hasegawa et al., 2000; ElShabrawi et al., 2010; Nounjan and Theerakulpisut, 2012) where an increase in catalase and peroxidase activity in rice cultivars were recorded with increasing salt concentrations(Mittal and Dubey, 1991; Yaghubi 2014 and Joseph et al., 2015). Proline is the most common compatible solute that plays an important role in osmotic adjustment. It also suppresses production of free radicals (Hasegawa et al., 2000; Okuma et al., 2004). Also proline contributes to the protection of membranes, proteins and enzymes from damaging effects of salinity stress (Hossain et al., 2014).

Leaf pigments, photosynthesis, stomata conductance, growth, yield and yield components were significantly declined by increasing salinity levels up to $8.5 \mathrm{dSm}^{-1}$. Amino acids, $\mathrm{Na}^{+1}, \mathrm{Ca}^{+2}, \mathrm{Na}^{+} / \mathrm{K}^{+}$and $\mathrm{Na}^{+1 /} \mathrm{Ca}^{+2}$ and unfilled grain in the terms of sterility were significantly increased with increasing salinity level,(Zayedet al., 2014). Selection of salt tolerant cultivars is one of the most effective methods to increase the productivity of saline soils; thereby the aim of current study was to identify the optimum criteria for salinity tolerance in rice.

\section{MATERIALS AND METHODS}

Twofield experiments were conducted at El-Sirw Agricultural Research Station, Damietta Governorate, Egyptduring 2015 and 2016 seasons. Each experiment associated to each salinity level was laid in randomized complete block design with four replications. Three salinity levelsviz; 2,6 and $10 \mathrm{ds} \mathrm{m}^{-1}$. The tested salinity levels were determined after soil survey and measuring Ece of different sites then selected the current studied levels.

Four rice varieties, namely; Giza177, Giza178, Giza179 and Egyptian Hybrid One were used in this 
study. Soil texture was clayey. Soil samples were taken before land preparation at the depth of 0-30 $\mathrm{cm}$ from the soil surface. The soil samples were completely mixed, dried and grounded, and then physically and chemically analyzed according to Black et al. (1965).

Table1.Thechemical analysis of the experimental sites during 2015 and 2016 seasons

\begin{tabular}{|c|c|c|c|c|c|c|c|c|c|c|c|c|c|}
\hline \multirow{2}{*}{$\begin{array}{l}\text { Salinity } \\
\text { levels }\end{array}$} & \multirow{2}{*}{ seasons } & \multirow{2}{*}{$\begin{array}{c}E C \\
\left(\mathrm{dSm}^{-1}\right)\end{array}$} & \multirow{2}{*}{$\mathbf{p H}$} & \multirow[b]{2}{*}{$\mathbf{N a}^{+}$} & \multicolumn{6}{|c|}{ Cation and anion meq $\mathrm{L}^{-1}$ (soil paste) } & \multicolumn{3}{|c|}{ Available ppm } \\
\hline & & & & & $\mathrm{Ca}^{++}$ & $\mathbf{M g}^{++}$ & $\mathbf{K}^{+}$ & $\mathrm{HCo}_{3}^{-}$ & $\mathrm{Cl}^{-}$ & $\mathrm{SO}_{4}^{--}$ & $\mathbf{N}$ & $\mathbf{P}$ & $\mathbf{K}$ \\
\hline$\overline{\mathrm{S} 1}$ & & 2.0 & 8.2 & 13.1 & 4 & 3 & 1.40 & 6 & 11 & 3.0 & 34 & 18 & 487 \\
\hline S2 & 2015 & 6.0 & 8.1 & 30 & 14 & 16 & 0.36 & 7 & 35 & 18 & 31 & 14 & 311 \\
\hline $\mathrm{S} 3$ & & 10 & 8.0 & 49.0 & 31 & 20 & 0.31 & 14 & 40 & 36 & 24 & 11 & 300 \\
\hline $\mathrm{S} 1$ & & 2.0 & 7.8 & 12.1 & 5 & 3 & 1.42 & 6 & 11 & 3.0 & 33 & 19 & 483 \\
\hline S2 & 2016 & 6.0 & 8.0 & 28 & 17 & 15 & 0.34 & 7 & 35 & 18 & 31 & 14 & 310 \\
\hline S3 & & 10 & 8.2 & 50.0 & 26 & 24 & 0.30 & 14 & 43 & 33 & 24 & 12 & 298 \\
\hline
\end{tabular}

Seeds were sownon April, $25^{\text {th }}$ and the seedlings of 30 days age were transplanted at 20X $20 \mathrm{~cm}$ spacing in both seasons. The phosphorus and potassium fertilizers were applied in the forms of calcium super phosphate $\left(15.5 \% \mathrm{P}_{2} \mathrm{O}_{5}\right)$ and potassium sulphate $\left(48 \% \mathrm{~K}_{2} \mathrm{O}\right)$ in the rates of $37 \mathrm{~kg} \mathrm{P}_{2} \mathrm{O}_{5}$ and $50 \mathrm{k}_{2} \mathrm{Oha}^{-1}$,respectively. Nitrogen in the form of urea $(46.5 \% \mathrm{~N})$ was added into three equal splits, 1/3 at 15, 30 and 45 days after sowing at the abovementioned levels. Zinc fertilizer at the rate of $24 \mathrm{~kg}$ $\mathrm{ZnSO}_{4} \mathrm{ha}^{-1}$ was mixed with sand and manually broadcasted at the beginning of flooding. Then, the irrigation treatments were applied as aforementioned. Each Irrigation treatment was tightly surrounded by deep ditches with $2 \mathrm{~m}$ wide and $1 \mathrm{~m}$ depth to isolate each other. The plot size was $10 \mathrm{~m}^{2}(2 \mathrm{~m}$ width* $5 \mathrm{~m}$ length).

Growth characteristics and Photosynthetic Pigments:

At heading stage, plants of five hills wererandomly taken from each plot to estimate flag leaf area and chlorophyll content. Flag leaf area of plant samples were measured by Portable Area Meter (Model LI- 3000A). Total chlorophyll content was determined in ten flag leaf by using chlorophyll meter (Model-SPAD502) Minolta Camera Co. Ltd., Japan. Samples of three hills from each plot were taken to determine.

Dry matter accumulation, photosynthetic pigments (chlorophyll a, chlorophyll b and total chlorophyll) using the spectro-photometric method according to Moran, 1982.Relative water content (RWC \%) was measured according to Ritchie and Nguyen, (1990)

Determination of antioxidants and minerals content:

Proline content of leaves was determined according to the method of Bates et al., (1973).

Enzyme extraction: Leaf sample (500 $\mathrm{mg}$ ) was frozen in liquid nitrogen and finely ground by pestle in a chilled motor, the frozen powder was added to $10 \mathrm{~mL}$ of phosphate buffer $(\mathrm{pH}$ 7.0). The homogenate was centrifuged at $15000 \times \mathrm{g}$ for $10 \mathrm{~min}$ at $4^{\circ} \mathrm{C}$ and supernatant was used as enzyme source for catalase (CAT; EC 1. 11. 1. 6), peroxidase (POD; EC 1. 11. 1. 7) Assays of antioxidant enzyme activities:

Assay of CAT activity: The assay mixture in volume of $3 \mathrm{~mL}$ contained $0.5 \mathrm{~mL}$ of $0.2 \mathrm{M}$ phosphate buffer $(\mathrm{pH}$ 7.0), $0.3 \mathrm{~mL}$ of (v/v) $\mathrm{H}_{2} \mathrm{O}_{2}$ and $0.1 \mathrm{ml}$ of enzyme. The final volume was made $3 \mathrm{ml}$ by adding distilled water. Change in optical density was measured at $240 \mathrm{~nm}$ at 0 min and 3 min on UV-Vis spectrophotometer. (Aebi and Bergmeyer, 1983 and Lum et al., 2014). Assay of POD activity: The assay mixture of $3 \mathrm{ml}$ contained $1.5 \mathrm{ml}$ of
$0.1 \mathrm{M}$ phosphate buffer ( $\mathrm{pH} 7.0), 1 \mathrm{ml}$ freshly prepared $10 \mathrm{mMguaiacol}, 0.1 \mathrm{ml}$ enzyme extract and $0.1 \mathrm{ml}$ of $12.3 \mathrm{mM} \mathrm{H}_{2} \mathrm{O}_{2}$. Absorbance was read at $436 \mathrm{~nm}$ and then increase in the absorbance was noted at the interval of $30 \mathrm{~s}$ on UV-Vis spectrophotometer. (Jebara et al., 2005 andLum et al., 2014).

Potassium (K) and sodium $(\mathrm{Na})$ were determined using Flame Photometer according to Chapman and Pratt (1978).

\section{Yield and yield attributes:}

At harvest, plant height was estimated; ten panicles were collected randomly to estimate the panicle weight, panicle length, number of filled grains and unfilled grains per panicle and 1000-grain weight. The six inner rows of each plot were harvested, dried, threshed, and the grain yield was determined at the moisture content of $14 \%$, the yield converted to grain yield ton $/ \mathrm{ha}^{-1}$.

Before the computations of the combined experiments, it is necessary to determine whether the error variances of the tests are homogenous to test the homogeneity of variance. After Combined analysis, the data were statically analyzed in split plot.All statistical analysis was performed using analysis of variance technique by means of "Co-STAT" computer software package. The treatment means were compared using least significant differences.

\section{RESULTS AND DISCUSSION}

The results of the present study will be discussed under the following topics;

A- Some physiological characteristics

B- Growth characteristics

C-Yield and its attributes

\section{A- Some physiological characters:}

The potassium, sodium and $\mathrm{Na} / \mathrm{K}$ ratio values were significantly affected by different salinity levels in couple study seasons (Table 2). As salinity level raised, $\mathrm{Na}$ and $\mathrm{Na} / \mathrm{K}$ ratio was gradually increased while the potassium was markedly declined attributed to antagonism (Table 2).

Data listed in Table 2 revealed that different salinity levels had a significant effects onpotassium $\%$, sodium $\%$ and $\mathrm{Na}^{+} / \mathrm{K}^{+}$ratio of rice varieties in both seasons. Increasing salinity levels gradually minimized potassium percentage. Similar to the last point, increasing salinity levels significantly raised sodium percentage as well as, $\mathrm{Na}^{+} / \mathrm{K}^{+}$ratio. 
Table 2. Potassium(K)\%, sodium(Na) $\%$ and $\mathrm{Na}^{+} / \mathrm{K}^{+}$ ratio of rice varieties as affected by salinity levelsdS m $\mathrm{m}^{-1}$ in 2015 and 2016 seasons.

\begin{tabular}{|c|c|c|c|c|c|c|}
\hline Characters & & $\%$ & & $\%$ & $\mathrm{Na}$ & \\
\hline Treatments & 2015 & 2016 & 2015 & 2016 & 2015 & 2016 \\
\hline & Salin & ty leve & ls $(\mathrm{dS}$ & $n-1)$ & & \\
\hline 2 & 2.85 & 2.98 & 0.78 & 0.75 & 0.27 & 0.25 \\
\hline 6 & 2.01 & 2.18 & 1.37 & 1.60 & 0.68 & 0.73 \\
\hline 10 & 1.35 & 1.27 & 1.93 & 1.79 & 1.43 & 1.41 \\
\hline LSD at 0.05 & 0.05 & 0.26 & 0.03 & 0.03 & 0.72 & 0.12 \\
\hline & & Vari & ties & & & \\
\hline Giza 177 & 1.00 & 1.33 & 1.86 & 1.88 & 1.86 & 1.41 \\
\hline Giza 178 & 2.36 & 2.51 & 1.33 & 1.22 & 0.56 & 0.49 \\
\hline Giza 179 & 2.64 & 2.87 & 1.04 & 1.01 & 0.39 & 0.35 \\
\hline EHR1 & 2.93 & 2.89 & 1.13 & 1.15 & 0.38 & 0.40 \\
\hline LSD at 0.05 & 0.07 & 0.20 & 0.02 & 0.03 & 0.41 & 0.16 \\
\hline Interaction & NS & NS & NS & NS & NS & NS \\
\hline
\end{tabular}

Amirjani(2010) and Zayed et al. (2014) came to similar trends. The tested rice varieties had significant variation intheirpotassium, sodium $(\%)$ and $\mathrm{Na}^{+} / \mathrm{K}^{+}$ ratio. EHR1 rice varietyhad higher potassium $\%$ and low sodium as well as $\mathrm{Na}^{+} / \mathrm{K}^{+}$, compared with other rice varieties, followed by Giza 179, Giza178 came in the third rank.Giza177 rice variety gave the lowest potassium content and high sodium (\%) as well as $\mathrm{Na}^{+} / \mathrm{K}^{+}$ratio. The obtained data indicate that the salt sensitive variety Giza 177 did not have any mechanismreacted to ion selectivity and the opposite was fact true with other tested varieties. The salt tolerant varieties had antiporters related $\mathrm{K}^{+}$selectivity which may increase $\mathrm{K}$ uptake against $\mathrm{Na}+$ uptake reducing $\mathrm{Na}^{+} / \mathrm{K}^{+}$ratio (Hossain et al., 2014 and Zayed et al., 2014).

Table 3. Some photosynthetic pigments as affected by salinity levels $\left(\mathrm{dS} \mathrm{m}^{-1}\right)$ and rice varieties during 2015 and 2016 seasons

\begin{tabular}{|c|c|c|c|c|c|c|c|c|}
\hline \multirow{2}{*}{$\begin{array}{l}\text { Characters } \\
\text { Treatments }\end{array}$} & \multicolumn{2}{|c|}{$\begin{array}{c}\text { Chlorophyll a } \\
\left(\mu \mathrm{g} \mathrm{ml}^{-1}\right)\end{array}$} & \multicolumn{2}{|c|}{$\begin{array}{c}\text { Chlorophyll b } \\
\left(\mu \mathrm{g} \mathrm{ml}^{-1}\right)\end{array}$} & \multicolumn{2}{|c|}{$\begin{array}{l}\text { total Chlorophyll } \\
\left(\mu \mathrm{g} \mathrm{ml}^{-1}\right)\end{array}$} & \multicolumn{2}{|c|}{$\begin{array}{l}\mathbf{a} / \mathbf{b} \\
\text { ratio }\end{array}$} \\
\hline & 2015 & 2016 & 2015 & 2016 & 2015 & 2016 & 2015 & 2016 \\
\hline \multicolumn{9}{|c|}{ Salinity levels $\left(\mathrm{dS} \mathrm{m}^{-1}\right)$} \\
\hline 2 & 15.80 & 16.79 & 6.53 & 6.74 & 22.33 & 23.54 & 2.44 & 2.44 \\
\hline 6 & 14.98 & 16.24 & 4.31 & 3.74 & 19.29 & 19.91 & 3.56 & 3.56 \\
\hline 10 & 13.92 & 15.40 & 3.12 & 3.07 & 17.04 & 18.47 & 4.67 & 4.67 \\
\hline LSD 0.05 & 0.41 & 0.38 & 0.82 & 1.35 & 1.21 & 2.04 & 0.79 & 1.92 \\
\hline \multicolumn{9}{|c|}{ Varieties } \\
\hline Giza 177 & 13.17 & 14.97 & 4.06 & 3.87 & 17.23 & 18.75 & 3.37 & 3.69 \\
\hline Giza 178 & 14.70 & 15.98 & 4.53 & 4.25 & 19.23 & 20.23 & 3.44 & 3.70 \\
\hline Giza 179 & 15.49 & 16.54 & 4.91 & 4.89 & 20.39 & 21.59 & 3.62 & 4.95 \\
\hline EHR1 & 16.24 & 17.08 & 5.11 & 5.05 & 21.35 & 21.97 & 3.78 & 4.95 \\
\hline LSD 0.05 & 0.59 & 0.64 & 0.49 & 0.87 & 0.63 & 0.89 & NS & 1.19 \\
\hline interaction & NS & $* *$ & NS & NS & NS & NS & NS & NS \\
\hline
\end{tabular}

The symbols of * and $* *$ indicate the significant at $5 \%$ and $1 \%$ levels probability, respectively, while NS means not significant.

Results in Table3 indicated that Chlorophyll a, Chlorophyll $\mathrm{b}$, total chlorophyll and chlorophyll $\mathrm{a} / \mathrm{b}$ ratiosignificantly affected by salt stress inthe two seasons, increased by increasingsalinity levels. On the other hand, chlorophyll $\mathrm{a} / \mathrm{b}$ ratio was increased by increasing salinity levels. Tested rice varieties showed great variation in their Chlorophyll $\mathrm{a}$, Chlorophyll $\mathrm{b}$ and total chlorophyll in the two seasons, while $\mathrm{a} / \mathrm{b}$ ratio was detected in the second season only.EHR1 showed the highest concentrations of chlorophyll a and Chlorophyll $\mathrm{b}$ and total chlorophyll as compared to other rice varieties. Giza179 rice variety came in the second ranking followed by Giza178, while the lowest concentrations of major pigments were found by Giza177 rice variety. The lowest value of chlorophyll a/b ratio was obtained by Giza177 without significant difference with Giza178. The highest value was obtained byGiza179 since they have the same value. The interaction between salinity levels and rice varieties had a significant effect on chlorophyll a in the second season only (Table5). Chlorophyll a content of rice varieties was minimized under high and medium salinity levels. EHR1 provided its superioritycompared with other tested rice varieties under normal condition as well as thetested salinity levels. Similar data were observed byAmirjani(2010) Hossain et al. (2014)and Zayed et al. (2014).

Data in Table 4 related to dry matter accumulation and relative water content as affected by salinity levels in 2015 and 2016 seasons. Dry matter accumulation and Relative water content significantly decreased by increasing salinity level from $2-10 \mathrm{~d} \mathrm{~S} / \mathrm{m}$ in both seasons. Relative water content of different rice varieties was markedly affected by salinity levels in both seasons. EHR1 variety without significant difference with Giza 179 produced the optimum values of relative water content and dry matter accumulation as compared with other varieties in the two seasons. Whereas, Giza 178 was the second order, Giza 177 gave the minimum values in the two seasons. The interaction between salinity levels and rice varieties had a significant effect on relative water content in the second season only (Table4). EHR1 gave the highest value of relative water content under normal conditions and the lowest one was obtained by Giza177 with higher salinity level (Table 5). High relative water content was found in the tolerant varieties implying that its ability to regulate its stomata conductance and their ability to adjust their osmatic pressure keeping high water content. Jahan et al. (2013) found similar trends. 
Table 4 . Dry matter accumulation (g) and relative water content (RWC \%) as affected by salinity levels $\left(\mathrm{dSm}^{-1}\right)$ and rice varieties during 2015 and 2016 seasons

\begin{tabular}{lcccc}
\hline Traits & \multicolumn{2}{c}{ dry matter accumulation (g) } & \multicolumn{2}{c}{ RWC (\%) } \\
& $\mathbf{2 0 1 5}$ & $\mathbf{2 0 1 6}$ & $\mathbf{2 0 1 5}$ & $\mathbf{2 0 1 6}$ \\
\hline \multicolumn{5}{c}{ Salinity levels (dS m-1) } \\
2 & 52.29 & 60.09 & 72.52 & 76.11 \\
6 & 39.26 & 53.08 & 68.61 & 71.94 \\
10 & 30.60 & 43.43 & 62.45 & 65.36 \\
LSD at 0.05 & 3.20 & 9.25 & 0.73 & 1.58 \\
\hline \multicolumn{5}{c}{ Varieties } \\
Giza 177 & 30.19 & 30.02 & 66.78 & 68.35 \\
Giza 178 & 41.29 & 50.48 & 67.75 & 71.42 \\
Giza 179 & 45.02 & 64.40 & 68.31 & 71.87 \\
EHR1 & 46.36 & 63.89 & 68.59 & 72.92 \\
LSD at 0.05 & 3.10 & 6.24 & 1.05 & 0.82 \\
interaction & $\mathrm{NS}$ & $\mathrm{NS}$ & $\mathrm{NS}$ & $* *$ \\
\hline
\end{tabular}

The symbols of * and $* *$ indicate the significant at $5 \%$ and $1 \%$ levels probability, respectively, while NS means not significant.

Table 5. Effect of the interaction between salinity levels (dS $\left.\mathrm{m}^{-1}\right)$ and rice varieties on Chlorophyll a $\left(\mu \mathrm{g} \mathrm{ml}^{-1}\right)$ during 2015 season and $\mathrm{RWC} \%$ during 2016 seasons.

\begin{tabular}{|c|c|c|c|c|c|c|}
\hline \multirow{2}{*}{$\begin{array}{r}\text { Characters } \\
\text { Salinity } \\
\text { levels }\end{array}$} & \multicolumn{3}{|c|}{ Chlorophyll a $\left(\mu \mathrm{g} \mathrm{ml}^{-1}\right)$} & \multicolumn{3}{|c|}{ RWC (\%) } \\
\hline & (2) & & & $20 \mathrm{~s}$ & & \\
\hline Varieties & & 2015 & & & 2016 & \\
\hline Giza177 & 16.17 & 15.10 & 13.64 & 74.99 & 69.39 & 60.66 \\
\hline Giza178 & 16.32 & 16.42 & 15.21 & 75.75 & 72.09 & 66.42 \\
\hline Giza179 & 16.81 & 16.58 & 16.23 & 76.54 & 72.87 & 66.20 \\
\hline EHR1 & 17.87 & $16.85 \mathrm{a}$ & 16.52 & 77.17 & 73.41 & 68.17 \\
\hline LSD at 0.05 & & 1.12 & & & 1.42 & \\
\hline
\end{tabular}

Table6. Some antioxidants as affected by salinity levels $\left(\mathrm{dS} \mathrm{m}^{-1}\right)$ and rice varieties during 2015 and 2016 seasons.

\begin{tabular}{|c|c|c|c|c|c|c|}
\hline \multirow[t]{2}{*}{ Characters } & \multicolumn{2}{|c|}{$\begin{array}{c}\text { Peroxidase (POD) } \\
\left(\mu \mathrm{mol} \mathrm{min} \mathrm{min}^{-1} \mathrm{~g}^{-1}\right. \\
\text { protein })\end{array}$} & \multicolumn{2}{|c|}{$\begin{array}{c}\text { Catalase (CAT) } \\
\left(\mu \mathrm{mol} \mathrm{min}{ }^{-1} \mathrm{~g}^{-1}\right. \\
\text { protein) }\end{array}$} & \multicolumn{2}{|c|}{$\begin{array}{c}\text { Proline } \\
\left(\mathrm{mg} \mathrm{g}^{-1} \mathrm{FW}\right)\end{array}$} \\
\hline & 2015 & 2016 & 2015 & 2016 & 2015 & 2016 \\
\hline \multicolumn{7}{|c|}{ Salinity levels $\left(\mathrm{dS} \mathrm{m}^{-1}\right)$} \\
\hline 2 & 1.85 & 2.19 & 0.086 & 0.049 & 0.16 & 0.22 \\
\hline 6 & 2.95 & 3.29 & 0.098 & 0.139 & 0.21 & 0.31 \\
\hline 10 & 4.65 & 5.13 & 0.161 & 0.295 & 0.32 & 0.42 \\
\hline LSD at 0.05 & 0.27 & 0.33 & 0.011 & 0.012 & 0.06 & 0.13 \\
\hline \multicolumn{7}{|c|}{ Varieties } \\
\hline Giza 177 & 1.09 & 1.09 & 0.084 & 0.072 & 0.12 & 0.21 \\
\hline Giza 178 & 1.87 & 1.87 & 0.109 & 0.103 & 0.24 & 0.33 \\
\hline Giza 179 & 4.08 & 4.08 & 0.127 & 0.129 & 0.27 & 0.36 \\
\hline EHR1 & 5.58 & 5.58 & 0.140 & 0.143 & 0.29 & 0.37 \\
\hline LSD at 0.05 & 0.23 & 0.26 & 0.009 & 0.01 & 0.031 & 0.044 \\
\hline Interaction & NS & NS & NS & NS & $* *$ & $* *$ \\
\hline
\end{tabular}

Data for antioxidant defense systemswhich represented in Peroxidase (POD), catalase (CAT) and proline contents are presented in (Table6). Increasing salinity levels dramatically raised antioxidant system.

Tested rice varieties showed great variation in their antioxidant system. EHR1 provided its superiority via increment POD, CAT(antioxidants enzymes) andProline (non-enzymatic antioxidant)which proposed to be important in plant stress tolerance. Giza 179 rice variety came in the second rank followed by Giza178. The lowest values of POD, CAT and proline were observed by Giza177. CAThad ap in the removal of $\mathrm{H}_{2} \mathrm{O}_{2}$ generated in peroxisomes by oxidases involved in b-oxidation offatty acids, photorespiration and purine catabolism. The CATisozymes have been studied extensively in higher plants and prolinecan be regarded as non-enzymatic antioxidants that microbes,plants require to mitigate the adverse effects of ROSPolidoros and Scandalios, (1999) and Chen (2005). The interaction between salinity levels and rice varieties had a significant effect on proline content in both seasons (Table 6). The three rice varietiesEHR1, Giza178 and Giza179 did not show any significantthe difference among them under higher salinity levels and produced the highest value of chlorophyll content. Giza177 gave the lowest value of proline content. Zayed et al. (2004) found that the differance in their salinity tolerance are associated with different performance of proline content under various salinity levels.

Table7. Effect of the interaction between salinity levels $\left(\mathrm{dS} \mathrm{m}^{-1}\right)$ and rice varieties on proline $\left(\mathrm{mg} \mathrm{g}^{-1} \mathrm{FW}\right)$ in 2015 and 2016 seasons.

\begin{tabular}{|c|c|c|c|}
\hline \multirow{2}{*}{$\begin{array}{l}\text { Traits } \\
\quad \text { Salinity level }\end{array}$} & \multicolumn{3}{|c|}{ Proline $\left(\mathrm{mg} \mathrm{g}^{-1} \mathrm{FW}\right)$} \\
\hline & $2 \mathrm{dS} \mathrm{m} \mathrm{m}^{-1}$ & $6 \mathrm{dS} \mathrm{m}^{-1}$ & $10 \mathrm{dS} \mathrm{m}^{-1}$ \\
\hline Varieties & \multicolumn{2}{|l|}{2015} & \\
\hline Giza177 & 0.082 & 0.217 & 0.317 \\
\hline Giza178 & 0.249 & 0.307 & 0.433 \\
\hline Giza179 & 0.270 & 0.349 & 0.457 \\
\hline EHR1 & 0.292 & 0.353 & 0.478 \\
\hline \multirow[t]{2}{*}{ LSD at 0.05} & \multicolumn{3}{|c|}{0.05} \\
\hline & \multicolumn{2}{|l|}{2016} & \\
\hline Giza177 & 0.082 & 0.217 & 0.317 \\
\hline Giza178 & 0.249 & 0.307 & 0.433 \\
\hline Giza179 & 0.270 & 0.349 & 0.457 \\
\hline EHR1 & 0.292 & 0.353 & 0.478 \\
\hline LSD at 0.05 & & 0.076 & \\
\hline
\end{tabular}

\section{B- Growth characters:}

Data in Tables 8 and 9 show that flag leaf area and chlorophyll content (SPAD value) were significantly affected by salinity levels in both seasons. Increasingsalinity levels gradually reduce flag leaf area and chlorophyll content as compared with normal conditions which gave the highest values of the mentioned traits in the two seasons. Salinity reduces the plantgrowth through osmotic effects which reduces the ability of plants to take up water and this causes reduction in growth. Furthermore, reducing water uptake under salt stress is combined with reducing nutrient uptake restricted biochemical and pigments development growth as well as metabolism. Also, salinity may be reduced the photosynthetic of plant to a level that cannot sustain growth. The results are in accordance with the findings of Shereen et al. (2005).

Rice varieties show significant difference in flag leaf area, chlorophyll content(SPAD value) and plant height in the two seasons (Tables 8 and 10). EHRlgave the highest value of flag leaf area, in both seasons. Giza178 rice variety gavethe highest value of chlorophyll content andcame in the second rank in plant height. Giza179 came in the second rank after EHR1 in flag leaf area. Giza177 gave the lowest values of aforesaid traits in both seasons. 
Table 8. Flag leaf area $\mathrm{cm}^{2}$ and chlorophyll content (SPAD value) of some rice varieties as affected by different salinity levelsdS $\mathrm{m}^{-1}$ in 2015 and 2016 seasons.

\begin{tabular}{|c|c|c|c|c|}
\hline \multirow{2}{*}{$\begin{array}{l}\text { Traits } \\
\text { Treatments }\end{array}$} & \multicolumn{2}{|c|}{$\begin{array}{c}\text { Flag leaf } \\
\text { area }\end{array}$} & \multicolumn{2}{|c|}{$\begin{array}{c}\text { Chlorophyll } \\
\text { content }\end{array}$} \\
\hline & 2015 & 2016 & 2015 & 2016 \\
\hline \multicolumn{5}{|c|}{ Salinity levelsdS m ${ }^{-1}$} \\
\hline 2 & 39.67 & 39.57 & 40.48 & 41.01 \\
\hline 6 & 22.30 & 22.33 & 39.81 & 40.34 \\
\hline 10 & 18.37 & 18.39 & 38.71 & 39.14 \\
\hline LSD0.05 & 0.27 & 0.46 & 0.44 & 0.59 \\
\hline \multicolumn{5}{|c|}{ Varieties } \\
\hline Giza177 & 21.39 & 21.37 & 37.63 & 38.00 \\
\hline Giza178 & 27.05 & 27.12 & 40.93 & 41.44 \\
\hline Giza179 & 27.30 & 27.23 & 39.36 & $39 \mathrm{~s} .93$ \\
\hline EHR1 & 27.30 & 31.35 & 40.75 & 41.29 \\
\hline LSD0.05 & 0.49 & 0.55 & 0.48 & 0.42 \\
\hline Interaction & $* *$ & $* *$ & $* *$ & $* *$ \\
\hline
\end{tabular}

Table 9. Effect of interaction between different salinity levels and rice varieties on flag leaf area and chlorophyll content of some rice varieties in 2015 and 2016 seasons.

\begin{tabular}{lcccccc}
\hline Traits & \multicolumn{3}{c}{ Flag leaf area } & \multicolumn{4}{c}{ Chlorophyll content } \\
Salinity levels & 2dS/m & $\mathbf{6 d S} / \mathbf{m}$ & $\mathbf{1 0 d S} / \mathbf{m}$ & $\mathbf{2 d S} / \mathbf{m}$ & $\mathbf{6 d S} / \mathbf{m}$ & $\mathbf{1 0 d S} / \mathbf{m}$ \\
\hline Varieties & 2015 & & \multicolumn{4}{c}{2015} \\
Giza177 & 33.5 & 18.26 & 12.42 & 41.33 & 38.33 & 33.25 \\
Giza178 & 39.33 & 22.4 & 19.42 & 39.66 & 42.37 & 40.75 \\
Giza179 & 40.36 & 22.07 & 19.46 & 39.40 & 38.58 & 40.10 \\
EHR1 & 45.50 & 26.56 & 22.18 & 41.53 & 39.97 & 40.75 \\
LSD at0.05 & & 0.85 & & \multicolumn{4}{c}{0.83} \\
\hline & 2016 & & & & 2016 & \\
Giza177 & 33.48 & 18.19 & 12.43 & 41.67 & 38.88 & 33.46 \\
Giza178 & 39.29 & 22.64 & 19.44 & 40.2 & 42.87 & 41.25 \\
Giza179 & 40.10 & 22.09 & 19.50 & 40.06 & 39.14 & 40.59 \\
EHR1 & 45.43 & 26.40 & 22.21 & 42.13 & 40.46 & 41.28 \\
LSD at0.05 & & 0.96 & & & 0.73 & \\
\hline
\end{tabular}

The interaction between salinity levels and rice varieties had a significant effect on flag leaf area, chlorophyll content and plant height in both seasonsTables (10\& 11). EHR1under normal condition produced the maximum values of flag leaf area, chlorophyll content and plant height in the two seasons. Giza178 rice variety under medium salinity level gave the highest value of chlorophyll content. The minimum values of the mentioned traits were obtained by Giza 177 under higher salinity levels in 2015 and 2016 seasons.

C-Yield components characters:

Panicle length, panicle weight, 1000- grain weight, filled grains and unfilled grains of rice varieties were influenced by salinity levels in both seasons (Table10, $12 \& 14)$. Increasing salinity levels significantly decreased panicle length, filled grains, panicle weight, and 1000 grain weight compared with normal condition in both seasons. On the contrary, unfilled grains was significantly increased by increasing salinity levels in the two seasons. The reduction in filled grains /panicle as salinity levels increasing is mainly attributed to raising unfilled grains that maybe a consequence of decreased pollen viability or decreased receptivity of the stigmatic surface. These results are confirmed with the findings ofAbdullah et al. (2001)

Rice varieties had a significant difference of panicle length, panicle weight, filled grains perpanicle, unfilled grainsper panicle and 1000 grain weight in the two seasons. The longest and heaviest panicle as well as, the highest value of filled grain was obtained by EHR1in both seasons thus gave. The highest value of unfilled grain and 1000-grain weight were in favor Giza177which gave the lowest values of panicle length, panicle weight, and filled grains.

Table 10. Plant height (cm), panicle length $(\mathrm{cm})$ and panicle weight $(\mathrm{g})$ of some rice varieties as affected by different salinity levels in 2015 and 2016 seasons.

\begin{tabular}{lcccccc}
\hline Traits & $\begin{array}{c}\text { Plant height } \\
\text { (cm) }\end{array}$ & \multicolumn{2}{c}{$\begin{array}{c}\text { Panicle } \\
\text { length( cm) }\end{array}$} & \multicolumn{2}{c}{$\begin{array}{c}\text { Panicle } \\
\text { weight }(\mathbf{g})\end{array}$} \\
Treatments & $\mathbf{2 0 1 5}$ & $\mathbf{2 0 1 6}$ & $\mathbf{2 0 1 5}$ & $\mathbf{2 0 1 6}$ & $\mathbf{2 0 1 5}$ & $\mathbf{2 0 1 6}$ \\
\hline \multicolumn{6}{c}{ Salinity levels $\left(\mathrm{dSm}^{-1}\right)$} \\
2 & 100.5 & 100.7 & 22.22 & 22.59 & 3.51 & 3.70 \\
6 & 93.62 & 93.78 & 19.66 & 20.04 & 2.65 & 2.84 \\
10 & 84.90 & 84.98 & 16.93 & 17.31 & 2.24 & 2.43 \\
LSD at0.05 & 0.15 & 0.55 & 0.17 & 0.28 & 0.10 & 0.11 \\
\hline \multicolumn{6}{c}{ Varieties } \\
Giza177 & 82.81 & 82.89 & 17.93 & 18.32 & 2.47 & 2.67 \\
Giza178 & 95.99 & 96.16 & 19.86 & 20.21 & 2.68 & 2.87 \\
Giza179 & 91.91 & 92.01 & 19.10 & 19.48 & 2.80 & 2.99 \\
EHR1 & 101.4 & 101.5 & 21.52 & 21.91 & 3.25 & 3.43 \\
LSD at0.05 & 0.29 & 0.57 & 0.28 & 0.28 & 0.098 & 0.12 \\
Interaction & $* *$ & $* *$ & $* *$ & $* *$ & $* *$ & $* *$ \\
\hline
\end{tabular}

Table 11. Effect of the interaction between different salinity levels and rice varieties on Plant height $(\mathrm{cm})$, panicle length $(\mathrm{cm})$ and Panicle weight (g) of some rice varieties in 2015 and 2016 seasons

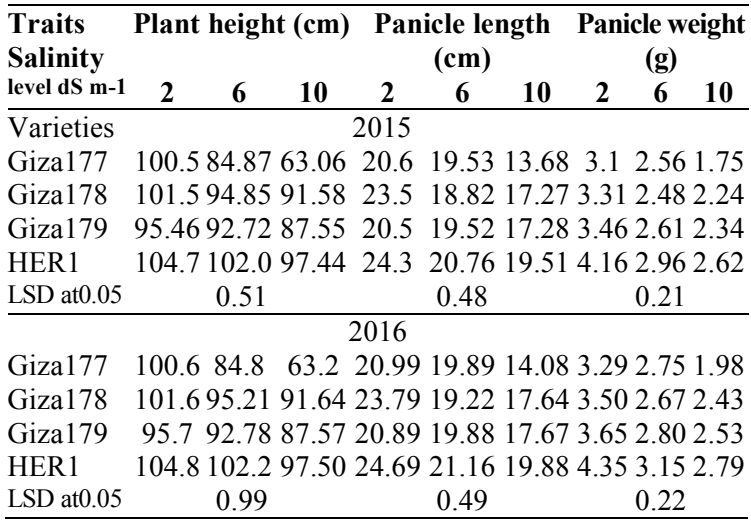

The interaction between salinity levels and some rice varieties had a significant effect on panicle length, panicle weight, filled grains, unfilled grains and 1000 grain weight in both seasons, Tables (11, 13\&15). EHR1under normal conditions gave the highest values of panicle length, panicle weight, filled grains per panicle and 1000 grain weight. The lowest values of unfilled grainper paniclewere observed by Gizaa177 under normal condition. Furthermore, EH1under higher salinity levels produced the lowest values of unfilled grainper panicle. Whereas, Giza177 under tested salinity 
levels gave the lowest values of panicle length, panicle weight, filled grainsper panicle and highest values of unfilled grainsper panicle.

Table 12. Number of filled grains/panicle and unfilled grains /panicle of some rice varieties as affected by different salinity levels in 2015 and 2016 seasons.

\begin{tabular}{|c|c|c|c|c|}
\hline Traits & \multicolumn{2}{|c|}{$\begin{array}{c}\text { Number of } \\
\text { filled grains / } \\
\text { panicle }\end{array}$} & \multicolumn{2}{|c|}{$\begin{array}{c}\text { Number of } \\
\text { unfilled grains / } \\
\text { panicle }\end{array}$} \\
\hline Treatment & 2015 & 2016 & 2015 & 2016 \\
\hline \multicolumn{5}{|c|}{ Salinity levels $\left(\mathrm{dSm}^{-1}\right)$} \\
\hline 2 & 149.1 & 151.0 & 14.25 & 14.85 \\
\hline 6 & 119.3 & 121.1 & 23.60 & 25.09 \\
\hline 10 & 84.44 & 85.6 & 42.43 & 43.22 \\
\hline LSD at0.05 & 0.81 & 1.13 & 1.89 & 0.69 \\
\hline \multicolumn{5}{|c|}{ Varieties } \\
\hline Giza177 & 90.84 & 92.27 & 31.60 & 32.28 \\
\hline Giza178 & 122.0 & 123.9 & 23.57 & 26.86 \\
\hline Giza179 & 114.1 & 115.6 & 25.72 & 26.56 \\
\hline HER1 & 143.5 & 145.2 & 31.60 & 25.18 \\
\hline LSD at0.05 & 1.39 & 1.16 & 1.78 & 0.91 \\
\hline Interaction & $* *$ & $* *$ & $* *$ & $* *$ \\
\hline
\end{tabular}

Table 13. Effect of the interaction between different salinity levels on Number of filled grains and unfilled grains of some rice varieties in 2015 and 2016 seasons

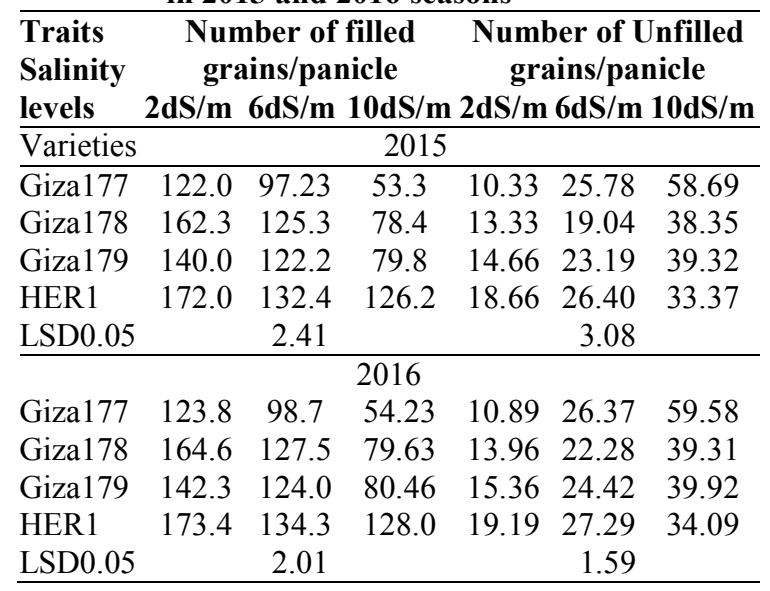

D- Grain yield:

As evident in Table14 grain yield of tested rice varieties influenced by salinity levels. Grain yield apparently decreased by increasing salinity levels, the highest value of grain yield was obtained under normal condition and the lowest one was obtained by higher salinity levels in both seasons. Salinity decreased grain yield through decreasing number of filled grains per panicle. Similar data wasobtained byKhatun and Flowers, (1995).

Rice varieties show that variation in grain yield EHR1gave the highest grain yield in both season, Giza 178 came in the second rank followed by Giza179. On the other side, Giza 177 gave the lowest value of grain yield in both seasons. Grain yield is depended on yield components and are severely affected by salinity, this results was confirmed by Khan et al., (1997).
The interaction between salinity levels and rice varieties had a significant effect on grain yield in both season (Table15). EHR1 under the normal condition was produced the highest value of grain yield. Thus, EHR1 gave the maximum values of grain yield under the medium and high salinity levels. On contrary, the lowest grain yield was produced by Giza177 under tested salinity levels in both seasons. The relative ranking between Giza178 and Giza179 was inconsistent under tested salinity levels in both seasons.

Table 14. 1000- grain weight (g) and Grain yield (t/ha) of some rice varieties as affected by different salinity levels in 2015 and 2016 seasons

\begin{tabular}{lcccc}
\hline Traits & \multicolumn{2}{c}{$\begin{array}{c}\text { 1000- grain } \\
\text { weight }(\text { g) }\end{array}$} & \multicolumn{2}{c}{ Grain yield(ton/ha) } \\
\cline { 2 - 5 } Treatments & $\mathbf{2 0 1 5}$ & $\mathbf{2 0 1 6}$ & $\mathbf{2 0 1 5}$ & $\mathbf{2 0 1 6}$ \\
\hline \multicolumn{4}{c}{ Salinity levels $\left(\mathrm{dSm}^{-1}\right)$} \\
2 & 24.45 & 24.77 & 10.77 & 10.90 \\
6 & 22.12 & 22.46 & 5.93 & 6.11 \\
10 & 21.16 & 21.56 & 4.05 & 4.17 \\
LSD at0.05 & 0.01 & 0.17 & 0.11 & 0.18 \\
\hline \multirow{5}{*}{ Varieties } & & \\
Giza177 & 25.33 & 25.66 & 4.67 & 4.84 \\
Giza178 & 19.01 & 19.37 & 7.38 & 7.50 \\
Giza179 & 24.33 & 24.64 & 7.23 & 7.37 \\
HER1 & 21.63 & 22.04 & 8.38 & 8.52 \\
LSD at0.05 & 0.16 & 0.28 & 0.13 & 0.16 \\
Interaction & $* *$ & $* *$ & $* *$ & $* *$ \\
\hline
\end{tabular}

The symbols of * and ** indicate the significant at $5 \%$ and $1 \%$ levels probability, respectively, while NS means not significant

Table 15. Effect of interaction between different salinity levels and rice varieties on flag leaf area, dry matter and chlorophyll content of some rice varieties in 2015 and 2016 seasons

\begin{tabular}{|c|c|c|c|c|c|c|}
\hline \multirow{2}{*}{$\begin{array}{l}\text { Traits } \\
\text { Salinity } \\
\text { levels }\end{array}$} & \multicolumn{3}{|c|}{ 1000- grain weight(g) } & \multicolumn{3}{|c|}{ Grain yield(ton/ha) } \\
\hline & $\begin{array}{c}2 \\
\mathrm{dSm}^{-1}\end{array}$ & $\begin{array}{c}6 \\
\mathrm{dSm}^{-1}\end{array}$ & $\begin{array}{c}10 \\
\mathrm{dSm}^{-1}\end{array}$ & $\begin{array}{c}2 \\
\mathrm{dSm}^{-1}\end{array}$ & $\begin{array}{c}6 \\
\mathrm{dSm}^{-1} \\
\end{array}$ & $\begin{array}{c}10 \\
\mathrm{dSm}^{-1}\end{array}$ \\
\hline Varieties & & & 2015 & & & \\
\hline$\overline{\text { Giza177 }}$ & 28.2 & 24.27 & 23.53 & 9.44 & 3.47 & 1.09 \\
\hline Giza178 & 21.13 & 18.49 & 17.41 & 10.63 & 6.67 & 4.84 \\
\hline Giza179 & 25.23 & 23.96 & 23.79 & 10.90 & 6.48 & 4.32 \\
\hline EHR1 & 23.23 & 21.75 & 19.91 & 12.10 & 7.10 & 5.94 \\
\hline LSD at 0.05 & & 0.28 & & & 0.23 & \\
\hline & & & 016 & & & \\
\hline iza177 & 28.52 & 24.67 & 23.81 & 9.63 & 3.67 & 1.24 \\
\hline Giza178 & 21.45 & 18.85 & 17.8 & 10.77 & 6.82 & 4.93 \\
\hline Giza179 & 25.59 & 24.27 & 24.08 & 11.06 & 6.63 & 4.42 \\
\hline EHR1 & 23.52 & 22.06 & 20.54 & 12.15 & 7.33 & 6.09 \\
\hline LSD at 0. & & 0.48 & & & 0.2 & \\
\hline
\end{tabular}

\section{REFERENCES}

Abdullah, Z.; M.A. Khan and T.J. Flowers(2001). Causes of sterility in seed set in rice under salinity stress. J. Agron. Crop Sci., 187: 25-32.

Aebi, H.E. and H.U. Bergmeyer (1983). Methods of enzymatic analysis, 3, Verlag Chemic, Deerfield Beach, FL.p273-286. 
Amirjani, M.R. (2011). Effect of salinity stress on growth, sugar content, pigments and enzyme activity of rice. Int. J. Bot, 7:73-81

Amirjani, M.R.(2010). Effect of $\mathrm{NaCl}$ on some physiological parameters of rice. EJBS. 3 (1): 6-16.

Anjum, S.A.; X.Xie;L.Wang; M.F.Saleem; C.Man, and W.Lei (2011). Morphological, physiological and biochemical responses of plants to drought stress. African J. Agric. Res., 6: 2026-2032.

Apel, K. and H.Hirt (2004).Reactive oxygen species: metabolism, oxidative stress, and signal transduction. Annu Rev. Plant Biol., 55:373-399.

Bates, L.S.; R.P. Waldenand I.D. Teare (1973).Rapid determination of free proline for water studies.Plant and Soil. 39: 205-208.

Black, C.A.; D.O. Evan's, L.E. Ensmunger, J.L. White, F.E. and R.C. Clark (1965). Methods of Soil Analysis. II. Chemical and Microbiological Properties, merican Soc. Argon Inc., Madison, Wisconsin, USA, pp. 32-122.

Chapman, H.D. and P.E. Pratt (1978). Methods of Analysis for Soils, Plants and Waters. Univ. of Calif.,Div. Agric. Sci. Priced Pub., 4034. pp: 50-169.

Chen, C.and M.B. Dickman(2005).Proline suppresses apoptosis in the fungal pathogen Colletotrichumtri folii, PNAS 102, 3459e3464.

Chutipaijit, S.;S. Cha-um and k.Sompornpailin (2011). High contents of proline andanthocyanin increase protective response to salinity in Oryza sativa L. spp. indica.Aust J Crop Sci. 5:1191-1198

El-Shabrawi, H.;B. Kumar; T,Kaul;M.K. Reddy; S.L.Singla-Pareek andS.K. Sopory(2010).Redox homeostasis, antioxidant defense, and methylglyoxal detoxification as markers for salt tolerance in pokkali rice. Protoplasma. 245:85-96.

Hasegawa, P.M.; R.A. Zhu;J. K. Bressanand H.J. Bohnert (2000). Plant cellular and molecular responses to high salinity. Annu Rev Plant Physiol Plant Mol Biol. 51:463-499.

Hossain, M.A.; M.A .Hoque; D.J .Burritt and M.Fujita (2014).Proline protects plants against abiotic oxidative stress: biochemical and molecular mechanisms. In: Ahmad P (ed) Oxidative damage to plants. Elsevier Inc, San Diego.

Iyengar, E.R.R and M.P. Reddy (1996). Photosynthesis in highly salt-tolerant plants. In: Pessaraki M (ed) Handbook of photosynthesis. Marcel Dekker, New York.pp 897-909

Jahan, M.S.; M.N.B. Nordin; M.K.B. Lah andY.M. Khanif(2013). Effects of Water Stress on Rice Production: Bioavailability of Potassium in Soil. Journal of Stress Physiology \& Biochemistry. 9(2): 97-107.

Jebara, C.; M. Jebara; F. Limam and M.E. Aouani (2005). Changes in ascorbate peroxidase, catalase, guaiacol peroxidase and superoxide dismutase activities in common bean (Phaseolus vulgaris) nodules under salt stress. J. Plant Physiol. 162: 929-936
Joseph E.A.;K.V. Mohanan and V. V. Radhakrishnan (2015).Effect of Salinityvariation on the quantity of antioxidant enzymes in some rice cultivars of North Kerala, India. Universal J. of Agric. Res. 3(3): 89-105

Khan, M.S.A.; A. Hamid and M.A. Karim (1997). Effect of sodium chloride on germination and seedlingcharacters of different types of rice (Oryza sativa L.).J. Agron. Crop Sci., 179: 163169.

Khatun, S. and T.J. Flowers(1995). Effects of salinity on seed set in rice. Plant Cell Environ. 18: 61-67.

Lafitte H.R., J.Ismail and A.Bennett (2004). Abiotic stress tolerance in rice for Asia: progress and the future. In:'New Directions for a Diverse Planet', Proc. 4th International Crop Science Congress. pp. 1-17.

Lum, M.S; M.M. Hanafi; Y. M.Rafii, and A. S. N.Akmar (2014).Effect of drought stress on growth, proline and antioxidant enzyme activities of upland rice. The Journal of Animal \& Plant Sciences. 24(5):1487-1493.

Mittal, R. and R.S. Dubey(1991).Behavior of peroxidases in rice: changes in enzyme activity and isoforms in relation to salt tolerance. Plant Physiol. Biochem. 29: 31-40.

Moran, R. (1982). Formulae for determination of chlorophyll pigments with N-N-dimethyl formamid. Plant Physiol., 69: 1376-1381.

Polidoros, N.A. and J.G. Scandalios (1999).Role of hydrogen peroxide and differentclasses of antioxidants in the regulation of catalase and glutathioneS-transferase gene expression in maize (Zea mays L.), Physiol. Plant. 106:112120 .

Noctor, G. and C.H. Foyer (1998)Ascorbate and glutathione: keeping active oxygen under control. Annu Rev Plant Physiol Plant Mol Biol. 49:249279.

Nounjan, N.and P. Theerakulpisut (2012). Effects of exogenous proline and trehalose on physiological responses in rice seedlings during salt-stress and after recovery. Plant Soil Environ. 58: 309-315.

Okuma, E.; Y. Murakami;Y.Shimoishi;M.Tadaand Y. Murata (2004.) Effects of exogenous application of proline and betaine on the growth of tobacco cultured cells under saline conditions. Soil Sci. Plant Nutr. 50:1301-1305.

Ritchie, S.W and H.T. Nguyen (1990). Leaf water content and gas exchange parameters of two wheat genotypes differing in drought resistance. Crop Sci., 30: 105 -111.

Shereen, A.; S. Mumtaz, S. Raza; M.A. Khan and S. Solangi(2005). Salinity effects on seedling growth and yield components of different inbred rice lines.Pakistan J. Bot., 37:131-139.

Surekha Rao, P. ; B. Mishra; S. R. Gupta and A. Rathore (2012). Physiological response to salinity and alkalinity of rice genotypes of varying salt tolerance grown in field lysimeters. Journal of Stress Physiology \& Biochemistry. 9 (1):54-65. 
Yaghubi, M. (2014).The effects of salinity on antioxidantenzymes activity in the leaves of two contrast rice (Oryza sativa L.) cultivars. International Journal of Biosciences, 4: 116-125.

Zayed, B.A.; A.T. Badawi; S. A. Ghanem; S.M. Shehata and A.E. Abdel-Wahab (2004).Effect of three salt levels on growth of three rice cultivars differing in salt tolerance. Egypt. J. of Agric. Res., 82(1):219-231.
Zayed, B. A.; K. A. Salemand A.M Osama (2014). Physiological characterization of Egyptian salt tolerant rice varieties under different salinity levels. Life Sci. J., 11(10):1264-1272.

\section{بعض مضادات الأكسدة والصفات الفسيومورفولوجيه ومحصول الحبوب لبعض أصناف الأرز المتـأثرة بمستويات مختلفة من الملوحه مداد

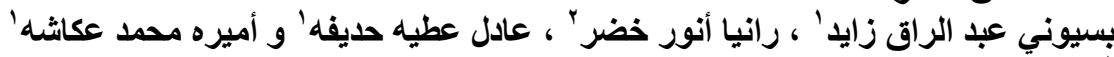

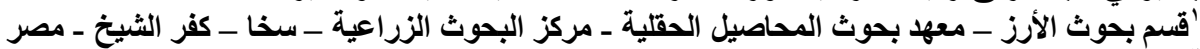

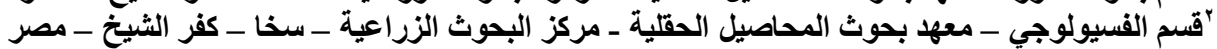

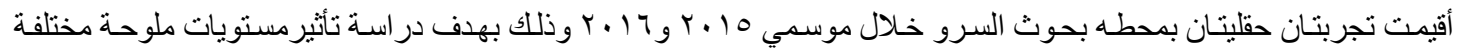

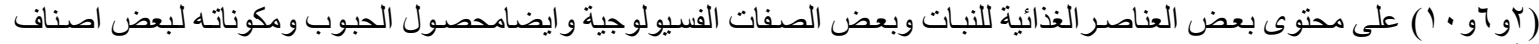

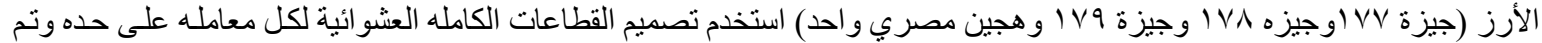

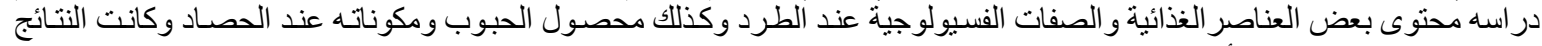

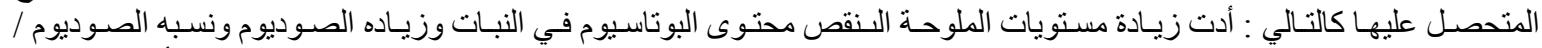

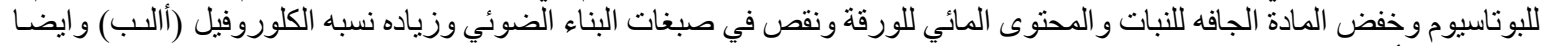

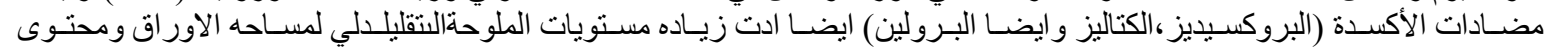

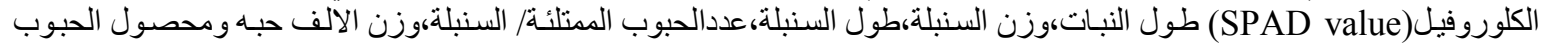

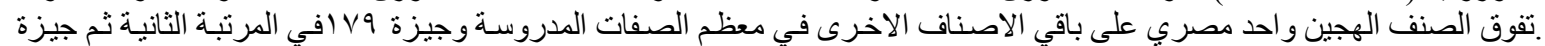

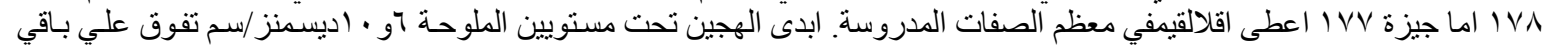

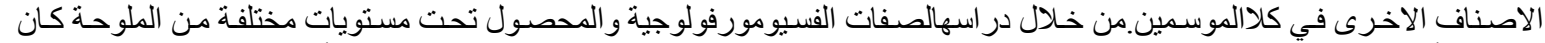

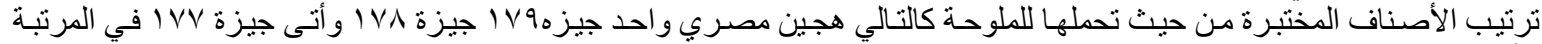

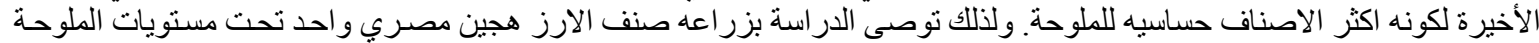

